\title{
Catalytic nanomedicine technology: copper complexes loaded on titania nanomaterials as cytotoxic agents of cancer cell
}

This article was published in the following Dove Press journal:

International Journal of Nanomedicine

7 February 2013

Number of times this article has been viewed

\section{Tessy Lopez ${ }^{1-3}$ \\ Emma Ortiz-Islas ${ }^{2}$ \\ Patricia Guevara ${ }^{4}$ \\ Esteban Gómez}

'Nanotechnology and Nanomedicine Laboratory, Metropolitan Autonomous University-Xochimilco, Coyoacán, México; ${ }^{2}$ Nanotechnology Laboratory, National Institute of Neurology and Neurosurgery "MVS," Tlalpan, México; ${ }^{3}$ Department of Chemical and Biomolecular Engineering, Tulane University, New Orleans, LA, USA;

${ }^{4}$ Neuroimmunology Laboratory, National Institute of Neurology and Neurosurgery “MVS," Tlalpan, México
Correspondence: Emma Ortiz-Islas Nanotechnology Laboratory, National Institute of Neurology and Neurosurgery “MVS," Insurgentes Sur 3877, La Fama, Tlalpan, 14269, México DF, México Tel +5255 56063822 ext 5034 Fax +525554240808 Emailemma170@hotmail.com
Abstract: The anticancer properties of pure copper (II) acetate and copper (II) acetylacetonate, alone and loaded on functionalized sol-gel titania $\left(\mathrm{TiO}_{2}\right)$, were determined in four different cancer cell lines (C6, RG2, B16, and U373), using increasing concentrations of these compounds. The copper complexes were loaded onto the $\mathrm{TiO}_{2}$ network during its preparation by the solgel process. Once copper- $\mathrm{TiO}_{2}$ materials were obtained, these were characterized by several physical-chemical techniques. An in vitro copper complex-release test was developed in an aqueous medium at room temperature and monitored by ultraviolet spectroscopy. The toxic effect of the copper complexes, alone and loaded on $\mathrm{TiO}_{2}$, was determined using a cell viability 3(4,5-dimethylthiazol-2-yl)-2,5-diphenyl-tetrazolium bromide (MTT) assay, when cancer cells were treated with increasing concentrations $(15.75-1000 \mathrm{mg} / \mathrm{mL})$ of these. Characterization studies revealed that the addition of copper complexes to the $\mathrm{TiO}_{2}$ sol-gel network during its preparation, did not generate changes in the molecular structure of the complexes. The surface area, pore volume, and pore diameter were affected by the copper complex additions and by the crystalline phases obtained. The kinetic profiles of both copper complexes released indicated two different stages of release: The first one was governed by first-order kinetics and the second was governed by zero-order kinetics. The cell viability assay revealed a cytotoxic effect of copper complexes, copper- $\mathrm{TiO}_{2}$, and cisplatin in a dose-dependent response for all the cell lines; however, the copper complexes exhibited a better cytotoxic effect than the cisplatin compound. $\mathrm{TiO}_{2}$ alone presented a minor cytotoxicity for $\mathrm{C} 6$ and $\mathrm{B} 16$ cells; however, it did not cause any toxic effect on the RG2 and U373 cells, which indicates its high biocompatibility with these cells.

Keywords: functionalized- $\mathrm{TiO}_{2}$, anticancer properties, toxic effect, cancer cell lines

\section{Introduction}

Cancer is among the five main causes of death and a major public health problem in the US and many other parts of the world. In USA alone, about 1,596,670 cancer cases were expected to be diagnosed in 2011. ${ }^{1}$ Cancer is a leading cause of death worldwide; it is estimated that around 12.7 million cancer cases and 7.6 million cancer deaths occurred in $2008 .^{2}$ It is a complex disease that arises from DNA mutations leading to an abnormal cell growth and cell cycle processes. There are different types of cancer, affecting various parts of the body. Each type of cancer is unique with its own causes, symptoms, and methods of treatment. Current treatment techniques for cancer include surgery, radiotherapy, chemotherapy, hyperthermia, immunotherapy, hormone therapy, stem cell therapy, and combinations thereof. ${ }^{3}$ Chemotherapy is used as treatment of many cancers, but it has important limitations including a lack of specificity that results 
in low concentrations of chemotherapeutic drugs/agents at tumor sites, along with numerous off-target toxic effects. ${ }^{4}$

Cisplatin (cis- $\left[\mathrm{PtCl}_{2}\left(\mathrm{NH}_{3}\right)_{2}\right]$; cis-Pt) is one of the most widely employed cytotoxic drugs in cancer therapy. Its activity as an anticancer agent was discovered approximately 40 years ago, ${ }^{5}$ and it became the first FDA-approved platinum (Pt) compound for cancer treatment in $1978 .{ }^{6}$ cis-Pt and Ptbased analogs, like carboplatin and oxaliplatin, are widely used as anticancer drugs and have proved to be beneficial in the treatment of a wide variety of solid tumors (head and neck, lung, bladder, testicular, ovarian, colorectal, and breast cancer) in various combination chemotherapy regimens. ${ }^{7}$ However, the major barriers that limit their use and efficacy are toxicity (particularly nephrotoxicity) and resistance, principally their side effects in normal tissues. ${ }^{8,9}$ Nevertheless, despite its toxicity, cis-Pt remains one of the most commonly used chemotherapy drugs due to its therapeutic efficacy. ${ }^{10}$

The discovery of the antitumor properties of cis-Pt and related Pt-compounds strongly suggested that perhaps other metal compounds were also active as cytostatic drugs. This led to a search for other less toxic, metal-based complexes that might be used as antitumor agents. At present, a number of copper $(\mathrm{Cu})(\mathrm{II})$ complexes have shown anticancer activity, whereby the organic ligand is responsible for directing the metal to different molecular targets. ${ }^{11,12}$ Various organic ligands coupled to $\mathrm{Cu}$ metal, such as terpyridines, ${ }^{13,14}$ hydrophilic alkyl phosphine, ${ }^{15}$ and moxifloxacin, ${ }^{16}$ among others, have been investigated in cancer mechanisms. Although a number of well-defined $\mathrm{Cu}$ (II) complexes exhibited DNA degradation capabilities, ${ }^{17,18}$ it has been found that the biological activity of some $\mathrm{Cu}$ complexes undergoes different mechanisms of action. Apparently, the inhibition of vital cell functions is related to interactions between $\mathrm{Cu}$ complexes and enzymes rather than to the induction of cross-linkings between the $\mathrm{Cu}$ complexes and DNA. ${ }^{12,19}$ As mentioned, $\mathrm{Cu}$ complexes containing bases as ligands are effective in reducing tumor size, delaying the metastasis, and significantly increasing the survival of patients.

Previous papers by Lopez et $\mathrm{al}^{20,21}$ have reported the anticancer properties of Pt compounds (Pt-acetylacetonate, chloroplatinic acid) different to cis-Pt loaded on titania $\left(\mathrm{TiO}_{2}\right)$ and silica materials. The results showed an effective reduction in tumor size when the $\mathrm{Pt}-\mathrm{TiO}_{2}$ or $\mathrm{Pt} / \mathrm{SiO}_{2}$ material was inoculated directly into the tumor (previously induced with C6 glioma line cells) of Wistar rats. Researchers also reported the reduction of the tumor, with consequent degradation of DNA due to the formation of complexes between $\mathrm{Pt}$ on $\mathrm{TiO}_{2}$ and phosphate groups in DNA, leading to cell death through an apoptotic mechanism. These results allowed us to propose that $\mathrm{Cu}$ complexes loaded on $\mathrm{TiO}_{2}$ may possess anticancer activity similar to the effects of Pt compounds. In a recent paper, we reported the toxic properties of copper acetate $\left(\mathrm{Cu}[\mathrm{Oac}]_{2}\right)$, alone and loaded on $\mathrm{TiO}_{2}$, upon cancer cells (C6 glioma cells). ${ }^{22}$ The most important finding was that $\mathrm{Cu}(\mathrm{Oac})_{2}$ alone, at low concentrations, had a highly toxic effect on cancer cells. As a sequel of that previous work, ${ }^{22}$ in the current paper we report the cytotoxic effect of $\mathrm{Cu}(\mathrm{Oac})_{2}$ and $\mathrm{Cu}$ (II) acetylacetonate $\left(\mathrm{Cu}[\mathrm{acac}]_{2}\right)$, alone and loaded on $\mathrm{TiO}_{2}$, on different cancer cell lines. Different goals were intended: (1) to determine the anticancer properties of the two aforementioned $\mathrm{Cu}$ complexes; (2) to study the ligand effect on the toxicity properties of the $\mathrm{Cu}$ complexes; (3) to determine the $\mathrm{Cu}$ complex release kinetics from $\mathrm{TiO}_{2}$ and its influence on cancerous cell death; and (4) to determine the mechanisms of cell death. The general purpose consisted of finding new alternative anticancer agents that are safer and cheaper than the currently used Pt-compounds and/or organic-based drugs.

\section{Methods}

\section{Sample preparation}

Functionalized- $\mathrm{TiO}_{2}$

In order to obtain a compatible $\mathrm{TiO}_{2}$ material, its surface was functionalized with sulphate, phosphate, and $\gamma$-aminobutyric acid (GABA) molecules using sulfuric acid (95.98\%) (REASOL, Iztapalapa, México City, México), phosphoric acid (85\%) (MONTERREY, Monterrey, Nuevo Leon, México) and GABA (99\%) (Sigma-Aldrich, St Louis, MO, USA) as precursors, according to the following procedure: First, $1 \mathrm{~g}$ of $\gamma$-aminobutyric acid was dissolved in a mixture of $115 \mathrm{~mL}$ of ethyl alcohol (96\%) (Alfimex, México City, México) and $72 \mathrm{~mL}$ of deionized water, under constant stirring. Then, five drops of sulfuric acid and phosphoric acid were added to the mixture, refluxed at $70^{\circ} \mathrm{C}$. Then, $70 \mathrm{~mL}$ of titanium n-butoxide (97\%) (Sigma-Aldrich) were slowly added dropwise to the acid mixture. After this point, the mixture was stirred and refluxed at $70^{\circ} \mathrm{C}$ during 24 hours. Finally, the water and ethanol excess was removed from the gel, and the resultant powder was dried at $70^{\circ} \mathrm{C}$ during 2 days.

\section{$\mathrm{Cu}(\mathrm{Oac})_{2} / \mathrm{TiO}_{2}$ and $\mathrm{Cu}(\mathrm{acac})_{2} / \mathrm{TiO}_{2}$ materials}

The $\mathrm{Cu}$ complexes used for this study were $\mathrm{Cu}(\mathrm{Oac})_{2}$ and $\mathrm{Cu}(\mathrm{acac})_{2}$ (99.99\%) (both Sigma-Aldrich). The amounts used were calculated to obtain molar ratios of water:alkoxide 16:1 and ethanol:alkoxide 8:1. The amount used of each $\mathrm{Cu}$ complex was $10 \% \mathrm{~mol}$ in $\mathrm{TiO}_{2}$. 
The procedure was as follows: the adequate amount of the $\mathrm{Cu}$ complex was dissolved in $115 \mathrm{~mL}$ of ethyl alcohol and $52 \mathrm{~mL}$ of deionized water, while $1 \mathrm{~g}$ of GABA was dissolved in $20 \mathrm{~mL}$ of deionized water. Both solutions were mixed and refluxed at $70^{\circ} \mathrm{C}$ under constant stirring. After this stage, the procedure followed the same steps required to prepare the sample of functionalized- $\mathrm{TiO}_{2}$.

\section{Characterization}

$\mathrm{N}_{2}$ adsorption-desorption

$\mathrm{N}_{2}$ adsorption-desorption isotherms were obtained to quantify the specific surface area $\left(\mathrm{S}_{\mathrm{BET}}\right)$ using the BET method and the pore volume $\left(\mathrm{V}_{\mathrm{p}}\right)$ and pore diameter $\left(\mathrm{D}_{\mathrm{p}}\right)$ using the $\mathrm{BJH}$ method. The samples were pretreated with vacuum at $70^{\circ} \mathrm{C}$ during 12 hours. After that, adsorption-desorption measurements were performed at liquid nitrogen temperature $(77 \mathrm{~K})$ in a Belsorp II (BEL Japan Inc, Osaka, Japan) gas adsorption apparatus over a relative pressure range of $0.01-0.99 \mathrm{P} / \mathrm{P}_{0}$.

\section{X-ray diffraction}

The X-ray powder diffraction patterns of the samples were measured in air at room temperature with a Bruker D-8 Advance diffractometer (Bruker Corp, Billerica, MA, USA) with the Bragg-Brentano $\theta-\theta$ geometry, $\mathrm{CuK} \alpha$ radiation, a $\mathrm{Ni} 0.5 \% \mathrm{Cu}-\mathrm{K} \beta$-filter in the secondary beam, and a 1-dimensional positive sensitive silicon strip detector (Linxeye; Bruker). The diffraction intensity, as a function of the angle $2 \theta$, was measured between $8^{\circ}$ and $90^{\circ}$, with a $2 \theta$ step of $0.030^{\circ}$, for $35.2 \mathrm{~s}$ per point.

\section{Transmission electronic microscopy}

Morphology of $\mathrm{Cu}(\mathrm{acac})_{2} / \mathrm{TiO}_{2}$ was studied by transmission electron microscopy. Using a JEOL- JEM-2100F electron microscope (JEOL Ltd, Tokyo, Japan) with an electron beam accelerated at $200 \mathrm{kV}$, and placing the sample on a gold grid with a holey carbon support film, micrographs were obtained from significant areas of the sample using the bright field technique, where crystalline parts in Bragg orientation appear dark and the amorphous or not Bragg-oriented parts appear bright. ${ }^{23}$

Some electron diffraction patterns were also obtained from the sample using the selected-area diffraction technique, which projects a parallel incident electron beam, accelerated at $200 \mathrm{kV}$, over the sample and photographs the diffracted beam pattern. The pattern is a scaled representation of a section of the reciprocal lattice; each spot represents a plane in the crystal that has been diffracted. ${ }^{24}$
The energy dispersive spectroscopy (EDS) spectra were obtained from the same zones where the micrographs were taken, using an Oxford EDS detector (Oxford Instruments, Abingdon, UK) cooled by liquid nitrogen.

\section{In vitro $\mathrm{Cu}(\mathrm{Oac})_{2}$ and $\mathrm{Cu}(\mathrm{acac})_{2}$ release tests}

The $\mathrm{Cu} / \mathrm{TiO}_{2}$ materials were compressed into a tablet of $\approx 10 \mathrm{mg}$ and immersed in $25 \mathrm{~mL}$ of deionized water at room temperature, under stirring. At predetermined times, an aliquot of $4 \mathrm{~mL}$ was removed for its measurement by ultraviolet spectroscopy, at $296 \mathrm{~nm}$ and $205 \mathrm{~nm}$ for the $\mathrm{Cu}(\mathrm{acac})_{2} / \mathrm{TiO}_{2}$ and $\mathrm{Cu}(\mathrm{Oac})_{2} / \mathrm{TiO}_{2}$ samples, respectively. After the measurement, the aliquot was returned to the initial solution. A calibration curve of absorbance versus known concentrations of the $\mathrm{Cu}$ complex was previously made. The released $\mathrm{Cu}$ complex amount was determined by interpolation of the obtained absorbance in each measure on the respective standard curve.

\section{In vitro tests on cell lines}

In vitro cell viability test

C6 and RG2 rat glioma cell lines, B16 line mouse melanoma cell lines, and the U373 human glioma cell line (American Type Culture Collection [ATCC], Rockville, MD, USA) were used for determining the cytotoxic properties of $\mathrm{Cu}$ compounds, alone and loaded on $\mathrm{TiO}_{2}$. The following procedure was performed in each cell line used: the cells were cultured under sterile conditions, at $37^{\circ} \mathrm{C}$ in a humid environment with $5 \% \mathrm{CO}_{2}$, in Dulbecco's modified Eagle's medium supplemented with $10 \%$ fetal bovine serum, 100 IU penicillin, $100 \mu \mathrm{g}$ streptomycin and $25 \mu \mathrm{g} / \mathrm{mL}$ amphotericin B. For quantification of cell viability, $1 \times 10^{5}$ cells were cultured in microtiter plates (96 wells) with $100 \mu \mathrm{L}$ of culture medium and then incubated overnight in a humidified atmosphere. The cells were treated with increasing concentrations (15.75 to $1000 \mathrm{mg} / \mathrm{mL}$ ) of $\mathrm{Cu}(\mathrm{Oac})_{2}, \mathrm{Cu}(\mathrm{acac})_{2}, \mathrm{Cu}(\mathrm{Oac})_{2} / \mathrm{TiO}_{2}$, $\mathrm{Cu}(\mathrm{acac})_{2} / \mathrm{TiO}_{2}, \mathrm{TiO}_{2}$, and cis- $\mathrm{Pt}$ (as a positive control) during 24 hours, at $37^{\circ} \mathrm{C}$. The effect of all the compounds on the cell survival was determined by the MTT assay (3[4,5-dimethylthiazol-2-yl]-2,5-diphenyl-tetrazolium bromide) (Roche Diagnostics GmbH. Roche Applied Science, Penzberg, Germany), which measures mitochondrial activity. After the exposure of the cells to each compound, $10 \mu \mathrm{L}$ of MTT were added to each well and left to rest during 4 hours; afterwards, $100 \mu \mathrm{L}$ of a buffer solution was added, and the plates were allowed to stand overnight at $37^{\circ} \mathrm{C}$. After checking for complete solubilization of the purple 
formazan crystals, the absorbance was measured at $570 \mathrm{~nm}$ (MICROELISA Minireader MR 590. Dynatech Laboratories INC, Alexandra, Virginia, USA). Each experiment was performed in triplicate.

\section{Preliminary cell death assays}

TdT-mediated dUTP nick end labeling (TUNEL) assay

To assess cell death in the cell lines after exposure to $\mathrm{Cu}$ compounds, we used the in situ Cell Death Detection Kit with Fluorescein (F Hoffman LaRoche) according to the manufacturer's recommendations. This kit labels DNA strand breaks, by terminal deoxynucleotidyl transferase (TdT), which catalyzes polymerization of labeled nucleotides to free $3^{\prime}-\mathrm{OH}$ DNA ends in a template-independent manner (TUNELreaction). Fluorescence of dead cells (green; labeling of DNA nicks) and of chromatin (blue; staining of chromatin with 4',6-diamidino-2-phenylindole [DAPI]) was detected by fluorescence microscopy with an inverted microscope (Leica DMLS; Leica Microsystems, Wetzlar, Germany).

\section{Cell viability by trypan blue test}

At the end of treatment with $\mathrm{Cu}$ compounds, the cells were washed with saline solution, treated with trypsin, recollected, and centrifuged. The cellular bottom was suspended in $1 \mathrm{~mL}$ of saline solution, and $10 \mu \mathrm{L}$ of this suspension was diluted in $90 \mu \mathrm{L}$ of a trypan blue solution $(1: 10)$. One drop of this suspension was put on a slide for morphologic observation in an optic microscope ( $\times 40$ field) (Carl Zeiss Meditec, Jena, West Germany).

\section{Results}

\section{X-ray diffraction}

The X-ray diffraction patterns of $\mathrm{Cu}(\mathrm{acac})_{2} / \mathrm{TiO}_{2}, \mathrm{Cu}(\mathrm{Oac})_{2} /$ $\mathrm{TiO}_{2}$, and $\mathrm{TiO}_{2}$ materials are shown in Figure 1. An amorphous phase mixed with a small quantity of anatase phase was indicated by the broad peak and the peak at 25.35 (attributed to the $1,0,1$, reflection of anatase), respectively, in the diffractogram of $\mathrm{TiO}_{2}$. When the $\mathrm{Cu}(\mathrm{acac})_{2}$ was added to the network of $\mathrm{TiO}_{2}$, an amorphous phase of $\mathrm{TiO}_{2}$ was observed. Besides, two strong signals at $2 \theta=11.35$ and $2 \theta=11.75$, respectively, were observed from the diffractogram of the $\mathrm{Cu}(\mathrm{acac})_{2} / \mathrm{TiO}_{2}$ sample. These signals were not identified in the current work; however, because similar signals were observed in a previous work where Pt-acetylacetonate was loaded on $\mathrm{TiO}_{2},{ }^{25}$ we suggest that a small quantity of titanium acetylacetonate was formed during the preparation of the sample. When the $\mathrm{Cu}(\mathrm{Oac})_{2}$ complex was incorporated onto the $\mathrm{TiO}_{2}$ network, only the amorphous phase was observed, as indicated by the undefined signals in the diffractogram

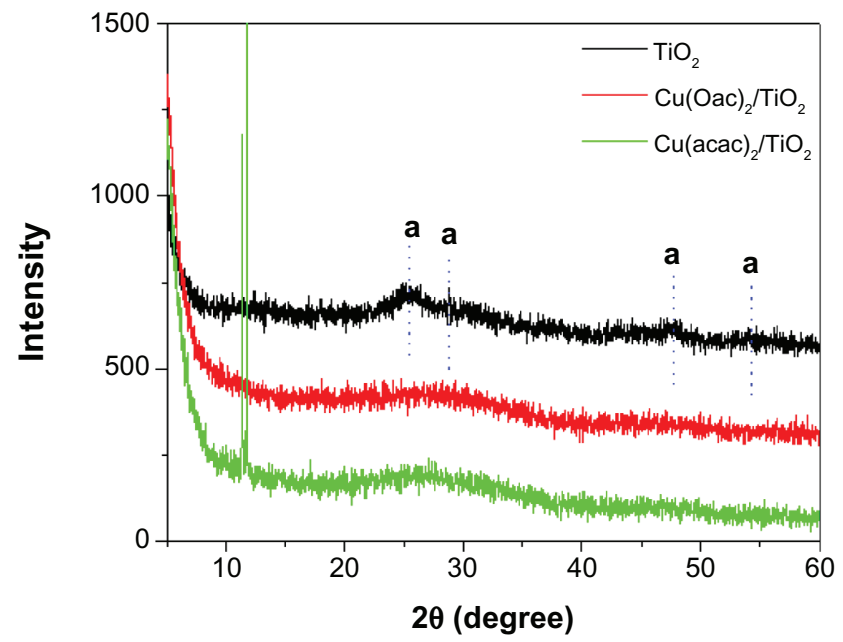

Figure I X-ray diffraction patterns of $\mathrm{TiO}_{2}$ and different copper complexes loaded on $\mathrm{TiO}_{2}$ materials $\left(\mathrm{Cu}[\mathrm{acac}]_{2}\right.$ and $\left.\mathrm{Cu}[\mathrm{Oac}]_{2}\right)$.

Abbreviations: a, anatase; $\mathrm{TiO}_{2}$, titania; $\mathrm{Cu}(\mathrm{acac})_{2}$, copper (II) acetylacetonate; $\mathrm{Cu}(\mathrm{Oac})_{2}$, copper (II) acetate.

of the $\mathrm{Cu}(\mathrm{Oac})_{2} / \mathrm{TiO}_{2}$ sample in Figure 1. Neither of the samples containing the $\mathrm{Cu}$ complex showed any signals of these complexes. This suggested that the $\mathrm{Cu}$ complexes were highly dispersed on the porous amorphous $\mathrm{TiO}_{2}$ network, as is typical of sol-gel materials. ${ }^{22}$ This observation is in accordance with those reported by Bokhimi et al. ${ }^{26}$ They reported a good dispersion of $\mathrm{Cu}$ on $\mathrm{TiO}_{2}$ when different $\mathrm{Cu}$ precursors were used to prepared sol-gel $\mathrm{Cu} / \mathrm{TiO}_{2}$ materials and when samples were studied by X-ray diffraction technique.

\section{High-resolution transmission electronic microscopy (HRTEM)}

$\mathrm{TiO}_{2}$ aggregates with a particle size of 1-10 nm approximately were formed, as is shown in the electronic micrographs, Figure 2. The HRTEM allows us to clearly see the atomic planes of the sample, with an interatomic distance of $2.4 \AA$. As there are always electrostatic forces between these particles, there were agglomerations of several particles, giving place to the formation of nanoparticle collections. The images suggest no significant presence of $\mathrm{Cu}$ in the crystalline $\mathrm{TiO}_{2}$ surface.

The EDS results confirmed the nanomaterial was almost purely $\mathrm{TiO}_{2}$ in the surface and in the whole structure, but it also shows the presence of small concentrations of copper, as expected by the sample preparation method. The dispersive energy bands shown are from titanium, oxygen and copper, with no overlapping peaks. A small peak appears around $2 \mathrm{keV}$ and should be ignored because it was caused by the gold grid where the sample was affixed.

The diffraction patterns are consistent with a polycrystalline sample, ${ }^{27}$ which means that the patterns were taken from 

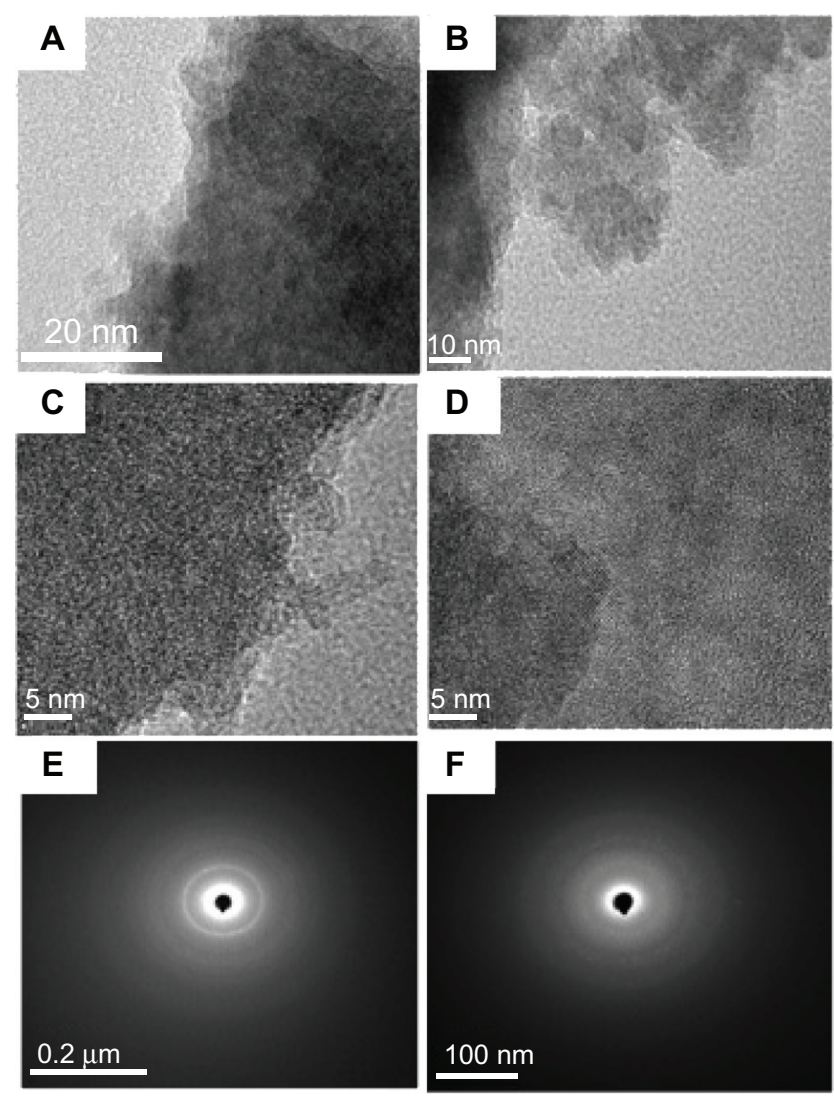

Figure 2 Transmission electronic micrographs of $\mathrm{Cu}(\mathrm{acac})_{2} / \mathrm{TiO}_{2}$ sample at different magnifications. (A) $\times 200,000$; (B) $\times 250,000$; (C and D) $\times 600,000$. (E and F) Electron diffraction pattern.

Abbreviations: $\mathrm{Cu}(\mathrm{acac})_{2}$, copper (II) acetylacetonate; $\mathrm{TiO}_{2}$, titania.

an area containing a large number of discrete segments of the same structure but with random orientations. This may be corroborated by the micrographs, which show that the particles do not have a preferred orientation.

\section{$\mathrm{N}_{2}$ adsorption-desorption}

The $\mathrm{N}_{2}$ adsorption-desorption isotherms of the $\mathrm{TiO}_{2}, \mathrm{Cu}(\mathrm{acac})_{2} /$ $\mathrm{TiO}_{2}$, and $\mathrm{Cu}(\mathrm{Oac})_{2} / \mathrm{TiO}_{2}$ samples are shown in Figure 3. According to the International Union of Pure and Applied Chemistry (IUPAC) classification, all the isotherms were Type IV, characteristic of mesoporous materials. ${ }^{28}$ At high relative pressures, $\mathrm{N}_{2}$ adsorption was not observed, indicating that macropores were not formed on the $\mathrm{TiO}_{2}$ network. The samples did not exhibit a hysteresis loop, implying that the nitrogen desorption procedure followed the same path as that of the nitrogen adsorption process. This observation suggests a probable existence of pores with cylindrical form.

The BET surface area $\left(\mathrm{S}_{\mathrm{BET}}\right)$, pore volume $\left(\mathrm{V}_{\mathrm{p}}\right)$, and average pore diameter $\left(d_{p}\right)$ data were determined from the $\mathrm{N}_{2}$ isotherms and are given in Table 1 . An effect on the textural properties of $\mathrm{TiO}_{2}$ was observed due to the $\mathrm{Cu}$ complex addition. The $\mathrm{S}_{\mathrm{BET}}$ value for $\mathrm{TiO}_{2}$ was $515 \mathrm{~m}^{2} / \mathrm{g}$, and this

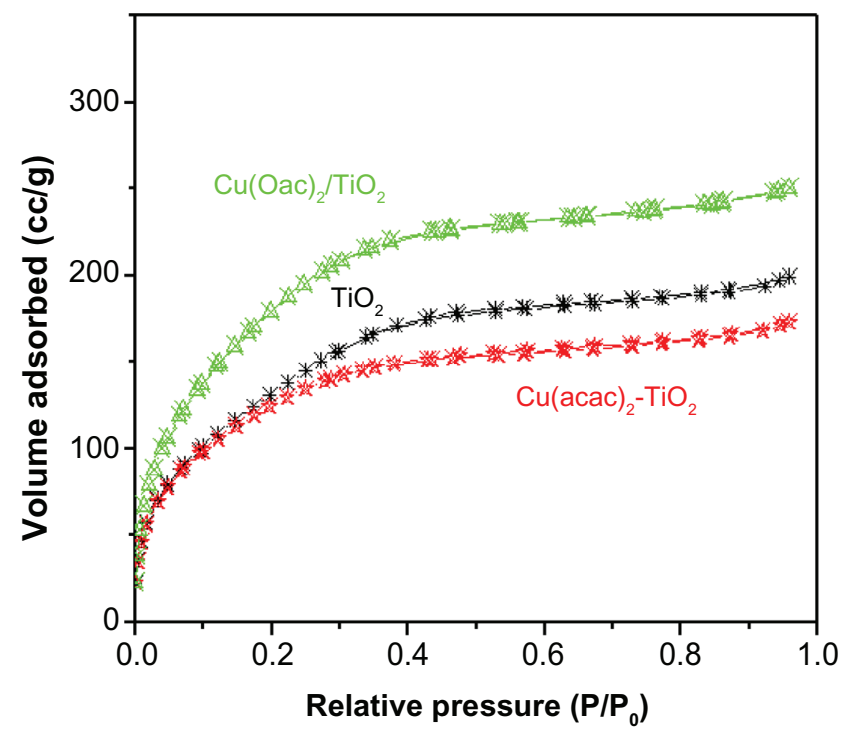

Figure $3 \mathrm{~N}_{2}$ adsorption-desorption isotherms of funtionalized-TiO ${ }_{2}, \mathrm{Cu}(\mathrm{acac})_{2} /$ $\mathrm{TiO}_{2}$ and $\mathrm{Cu}(\mathrm{Oac})_{2} / \mathrm{TiO}_{2}$ samples.

Abbreviations: $\mathrm{TiO}_{2}$, titania; $\mathrm{Cu}(\mathrm{acac})_{2}$, copper (II) acetylacetonate; $\mathrm{Cu}(\mathrm{Oac})_{2}$, copper (II) acetate.

decreased slightly to $461 \mathrm{~m}^{2} / \mathrm{g}$ when $\mathrm{Cu}(\mathrm{acac})_{2}$ was loaded. Currently, this decrement in area is attributed to a portion of $\mathrm{Cu}(\mathrm{acac})_{2}$ molecules that were deposited on the surface of the $\mathrm{TiO}_{2}$. However, when $\mathrm{Cu}(\mathrm{Oac})_{2}$ was loaded on $\mathrm{TiO}_{2}$, the $\mathrm{S}_{\mathrm{BET}}$ value increased to $684 \mathrm{~m}^{2} / \mathrm{g}$. Average diameter pore for all cases was similar: 2.4, 2.3, and $2.2 \mathrm{~nm}$ for $\mathrm{TiO}_{2}, \mathrm{Cu}(\mathrm{acac})_{2}$, and $\mathrm{Cu}(\mathrm{Oac})_{2}$, respectively. These values are within the IUPAC classification of mesopores; however, these pore sizes tend to be micropores. The pore volume for all $\mathrm{TiO}_{2}$ was approximately $0.30 \mathrm{cc} / \mathrm{g}$ : for $\mathrm{Cu}(\mathrm{acac})_{2} / \mathrm{TiO}_{2}$, it was $0.26 \mathrm{cc} / \mathrm{g}$; and for $\mathrm{Cu}(\mathrm{Oac})_{2} / \mathrm{TiO}_{2}$, it was $0.38 \mathrm{cc} / \mathrm{g}$ (Table 1$)$. The pore volume of $\mathrm{TiO}_{2}$ decreased when $\mathrm{Cu}(\mathrm{acac})_{2}$ was loaded on $\mathrm{TiO}_{2}$, presumably because $\mathrm{Cu}$-complex molecules were occluding the pores without filling them totally. Also, we have concluded that the textural properties depended on the crystalline phase obtained on each sample.

\section{In vitro release test}

Figure 4 displays the in vitro release profiles of $\mathrm{Cu}(\mathrm{acac})_{2}$ and $\mathrm{Cu}(\mathrm{Oac})_{2}$ from $\mathrm{TiO}_{2}$, carried out in an aqueous medium

Table I The BET method surface area $\left(\mathrm{S}_{\mathrm{BET}}\right)$, pore diameter $\left(\mathrm{D}_{\mathrm{p}}\right)$, and pore volume $\left(\mathrm{V}_{\mathrm{p}}\right)$ of $\mathrm{TiO}_{2}, \mathrm{Cu}(\mathrm{acac})_{2} / \mathrm{TiO}_{2}$, and $\mathrm{Cu}(\mathrm{Oac})_{2} /$ $\mathrm{TiO}_{2}$ samples

\begin{tabular}{llll}
\hline Sample & $\mathbf{S}_{\text {BET }}\left(\mathbf{m}^{2}\right) \mathbf{g}$ & $\mathbf{D}_{\mathbf{p}}(\mathbf{n m})$ & $\mathbf{V}_{\mathbf{p}}(\mathbf{c c} / \mathbf{g})$ \\
\hline $\mathrm{TiO}_{2}$ & 525 & 2.40 & 0.3080 \\
$\mathrm{Cu}(\mathrm{acac})_{2} / \mathrm{TiO}_{2}$ & 461 & 2.32 & 0.2677 \\
$\mathrm{Cu}(\mathrm{Oac})_{2} / \mathrm{TiO}_{2}$ & 684 & 2.26 & 0.3875 \\
\hline
\end{tabular}

Abbreviations: $\mathrm{TiO}_{2}$, titania; $\mathrm{Cu}(\mathrm{acac})_{2}$, copper (II) acetylacetonate; $\mathrm{Cu}(\mathrm{Oac})_{2}$, copper (II) acetate. 


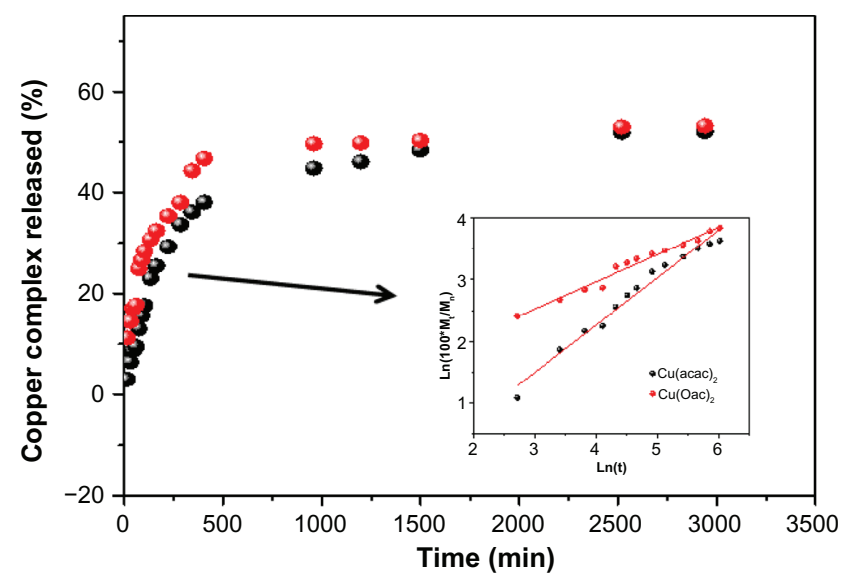

Figure 4 The in vitro release profiles of $\mathrm{Cu}(\mathrm{acac})_{2}$ and $\mathrm{Cu}(\mathrm{Oac})_{2}$ from titania, carried out at room temperature in an aqueous medium.

Notes: The insert shows the release kinetics profiles studied by fitting the Peppas equation to obtain the " $\mathrm{n}$ " values.

Abbreviations: $\mathrm{Cu}(\mathrm{acac})_{2}$, copper (II) acetylacetonate; $\mathrm{Cu}(\mathrm{Oac})_{2}$, copper (II) acetate.

at room temperature. The release profiles followed two steps: the first was governed by a fast delivery and was followed by a second stage in which a slower releasing rate was observed. Figure 4 shows that the amount of $\mathrm{Cu}(\mathrm{acac})_{2}$ released from $\mathrm{TiO}_{2}$ (solid black circles) was approximately $40 \%$ during a period of 6.5 hours, while at the same time, approximately $50 \%$ of $\mathrm{Cu}(\mathrm{Oac})_{2}$ (solid red circles) was released. During this period, the amount of $\mathrm{Cu}(\mathrm{Oac})_{2}$, released was slightly higher $(10 \%)$ than the amount of $\mathrm{Cu}(\mathrm{acac})_{2}$; however, $50 \%$ of both $\mathrm{Cu}$ complexes was released by 53 hours. After this, only approximately $10 \%$ was released. In our previous papers, we have found the same release profiles for other drugs released from silica or $\mathrm{TiO}_{2}$, and we assumed that the initial stage of the release corresponded to the drugs being weakly adsorbed on the surface of the pores, whereas the second stage of the liberation was dominated by the diffusion of the drug through the porous structure of the material. ${ }^{29,30}$

The release kinetics was studied by fitting the experimental data to the Peppas equation, which states that

$$
\mathrm{M}_{\mathrm{t}} / \mathrm{M}_{0}=\mathrm{kt}^{\mathrm{n}}
$$

where $M_{t}$ is the amount of drug released at time $t, M_{0}$ is the initial amount of drug loaded, $\mathrm{k}$ is a rate constant, and $\mathrm{n}$ is the diffusion exponent related to the diffusion mechanism. ${ }^{31}$ This model is widely used when the release mechanism is not well known or when more than one type of release phenomenon is involved. The $\mathrm{n}$ value may be used to characterize the diffusion release mechanism: the drug release is diffusioncontrolled when $\mathrm{n} \leq 0.5$, and it is swelling- or degradationcontrolled when $\mathrm{n} \geq 1$. For $0.5 \leq \mathrm{n} \leq 1$, the release kinetics is a superposition of both mechanisms. We calculated the kinetic constants $\mathrm{k}$ and the release exponents $\mathrm{n}$ obtained from the fits of the release curves of $\mathrm{Cu}$ complexes released from $\mathrm{TiO}_{2}$. The $\mathrm{n}$ values were obtained for the two different release steps observed in each sample and are reported in Table 2, while the insert in Figure 4 shows the fit lineal profile for the first release step of both samples. For the first step, the n values were 0.77 and 0.44 for $\mathrm{Cu}(\mathrm{acc})_{2}$ and $\mathrm{Cu}(\mathrm{Oac})_{2}$, respectively. The $\mathrm{n}$ values for the second step were 0.16 and 0.06 for $\mathrm{Cu}(\mathrm{acac})_{2}$ and $\mathrm{Cu}(\mathrm{Oac})_{2}$ loaded on $\mathrm{TiO}_{2}$, respectively. As the diffusion exponent $\mathrm{n}$ approached zero, the drug release rate remained constant until the exhaustion of the drug.

\section{In vitro cell-toxicity test}

Animal and cell lines have been commonly used as an in vitro tumor model to evaluate the anticancer effect of novel agent therapeutics. In this work, the cell lines used were: $\mathrm{C} 6$, which is a rat glial cell line; RG2, a rat glioblastoma cell line; B16, a mouse melanoma cell line; and U373, which is a human glioblastoma cell line. All these cell lines were used to determine the cytotoxic effect of $\mathrm{Cu}(\mathrm{acac})_{2}$ and $\mathrm{Cu}(\mathrm{Oac})_{2}$, alone as well as loaded on $\mathrm{TiO}_{2}$. The toxic effect was determined by comparison with the toxic effect exercised by cis-Pt, taking as reference the effects of $\mathrm{TiO}_{2}$ alone and with the untreated cells used as control. For this purpose, all the cell lines were treated with increasing amounts of each compound, maintaining untreated cells as control. To determine the cytotoxic effect, after exposure with the aforementioned chemicals, the number of viable cells were enumerated using a colorimetric MTT assay. ${ }^{32}$ The percentage of surviving cells with respect to untreated cells (control) was calculated using the following formula:

$$
\% \text { viability }=\left[\left(\mathrm{A}_{\mathrm{t}} / \mathrm{A}_{\mathrm{s}}\right) \times 100\right] \% \text {, }
$$

where $\mathrm{A}_{t}$ and $\mathrm{A}_{\mathrm{s}}$ indicate the absorbance of the sample and control, respectively. The MTT assay is based on the cleaving of the yellow tetrazolium salt (MTT) to purple formazan by metabolically active cells. The formazan crystals formed are

Table 2 Kinetic constants "k" and release exponents "n," obtained from Peppa's equation fits of the determined release

\begin{tabular}{|c|c|c|c|c|c|c|}
\hline \multirow[t]{2}{*}{ Sample } & \multicolumn{3}{|c|}{ First step } & \multicolumn{3}{|c|}{ Second step } \\
\hline & $\mathbf{n}$ & k & $\mathbf{r}$ & $\mathbf{n}$ & k & $\mathbf{r}$ \\
\hline$\overline{\mathrm{Cu}(\mathrm{acac})_{2} / \mathrm{TiO}_{2}}$ & 0.77 & 0.44 & 0.976 & 0.16 & 14.68 & 0.98 \\
\hline $\mathrm{Cu}(\mathrm{Oac})_{2} / \mathrm{TiO}_{2}$ & 0.44 & 3.30 & 0.973 & 0.06 & 31.50 & 0.97 \\
\hline
\end{tabular}
curves of copper complexes released from titania

Abbreviations: $\mathrm{Cu}(\mathrm{acac})_{2}$, copper (II) acetylacetonate; $\mathrm{TiO}_{2}$, titania; $\mathrm{Cu}(\mathrm{Oac})_{2}$, copper (II) acetate. 
solubilized, and the resulting colored solution is quantified at $570 \mathrm{~nm}$ using a multiwell scanning spectrophotometer (enzyme-linked immunosorbent assay [ELISA] reader). This assay provides quantitative and qualitative information about the cell survival by observing whether there is a color change. If the color of the solution does not change (yellow), this indicates there is cell death.

Results of MTT assays (Figure 5) clearly revealed the cytotoxic effect of $\mathrm{Cu}, \mathrm{Cu}-\mathrm{TiO}_{2}$, and cis-Pt, in a dose dependent manner, in all the cell lines; nevertheless, the $\mathrm{Cu}$ complex exerted better cytotoxic effects than the cis-Pt compound. $\mathrm{TiO}_{2}$ alone also showed a small cytotoxicity towards the two cancer cells (C6 and B16 cells); its effect was much less pronounced, compared with the rest of the chemicals used, and it did not exert any toxic effect on the RG2 and U373 cells, indicating its high biocompatibility with the cells. The $\mathrm{Cu}$ complexes loaded on $\mathrm{TiO}_{2}$ showed a lineal death cell in function of the amount of $\mathrm{Cu} / \mathrm{TiO}_{2}$ added to each cell line until a concentration of $250 \mathrm{mg} / \mathrm{mL}$; after this concentration the toxic effect was the same. $\mathrm{Cu}(\mathrm{Oac})_{2}$ was slightly more toxic than $\mathrm{Cu}(\mathrm{acac})_{2}$; however, low doses of both complexes alone were necessary to kill approximately $90 \%$ of cells $(\sim 62.5 \mathrm{mg} / \mathrm{mL})$, while when using $1000 \mathrm{mg} / \mathrm{mL}$ of cis-Pt, only a $20 \%$ of viability cell was observed. In the same way, when these complexes were loaded on $\mathrm{TiO}_{2}$ they had the same behavior, and $250 \mathrm{mg} / \mathrm{mL}$ of $\mathrm{Cu} / \mathrm{TiO}_{2}$ were necessary to obtain the same percentage of death cell $(90 \%)$. In summary, at low concentrations the effects of both $\mathrm{Cu}$ complexes were toxic enough to kill nearly $90 \%$ of all the cells. A greater amount of $\mathrm{Cu} / \mathrm{TiO}_{2}$ materials was necessary to obtain the same percentage of cell death, due to the fact that only a small quantity of this complex was released from $\mathrm{TiO}_{2}$ in each concentration used. However, the toxic effect was linear, indicating that the complex released is proportional to the mass used. Both $\mathrm{Cu}$ complexes alone and those loaded on $\mathrm{TiO}_{2}$ exerted better cytotoxic effects than cis-Pt.

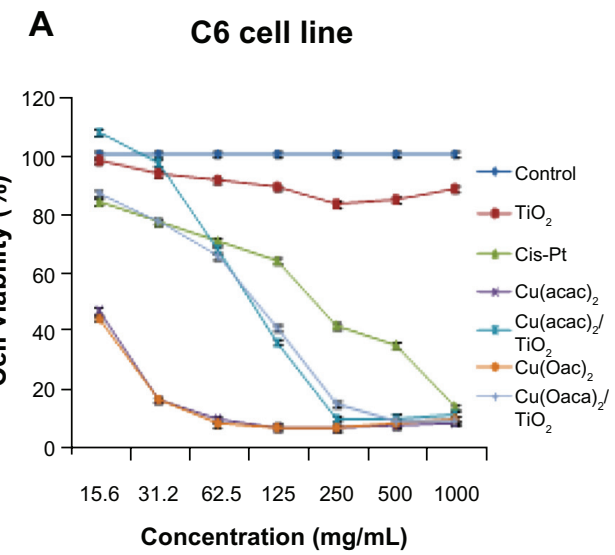

B

RG2 cell line

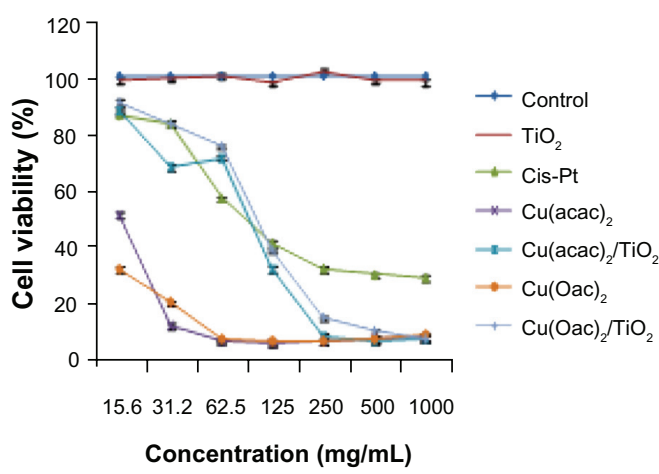

C B16 cell line

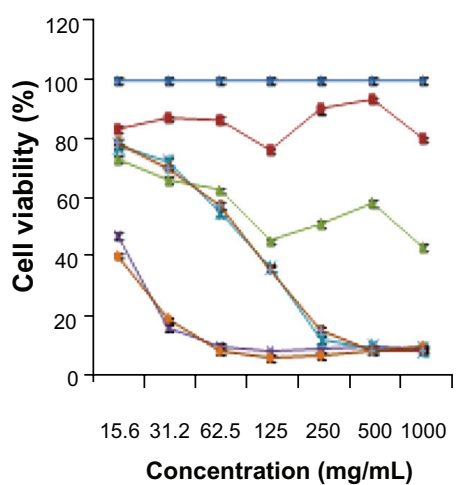

D

U373 cell line

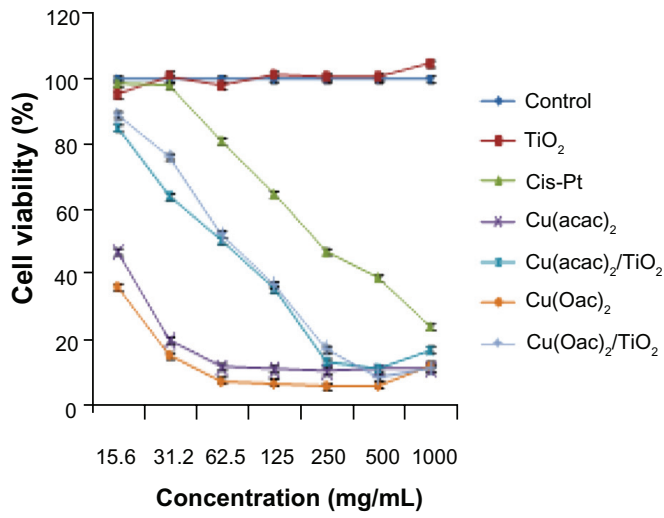

Figure 5 Dose response curves for $\mathrm{Cu}(\mathrm{Oac})_{2}, \mathrm{Cu}(\mathrm{acac})_{2}, \mathrm{Cu}(\mathrm{Oac})_{2} / \mathrm{TiO}_{2}, \mathrm{Cu}(\mathrm{acac})_{2} / \mathrm{TiO}_{2}, \mathrm{TiO}_{2}$, and cis-Pt, using (A) C6, (B) RG2, (C) BI6, and (D) U373 cell lines, following 24-hour incubation, as assessed by MTT assay.

Notes: In all cases, the copper complex alone and loaded with $\mathrm{TiO}_{2}$ produced the greatest concentration-dependent decrease in cellular proliferation, while $\mathrm{TiO}_{2}$ induced $10 \%$ less cell death in C6 and BI6 cells. cis-Pt was used as a positive control. Data are expressed as the mean of the triplicate determinations (mean \pm SD) in \% cell viability of untreated cells (100\%).

Abbreviations: $\mathrm{Cu}(\mathrm{Oac}) 2$, copper (II) acetate; $\mathrm{Cu}(\mathrm{acac})$, copper (II) acetylacetonate; $\mathrm{TiO}_{2}$, titania; cis-Pt, cisplatin; MTT, 3(4,5-dimethylthiazol-2-yl)-2,5-diphenyl-tetrazolium bromide; SD, standard deviation. 


\section{Assays for cell-death type}

After we observed by optical microscopy the formation of apoptotic bodies on cell previously treated with $\mathrm{Cu}(\mathrm{acac})_{2}$, a tunnel assay was made to corroborate that the cell death was carried out through an apoptotic mechanism. Morphologic observations, like cellular shrinkage and blending following $\mathrm{Cu}$-compound treatment, are shown in Figure 6. Figure 6A gives us an initial indication that the cell death may have been by an apoptotic mechanism. On the other hand, the TUNEL assay showed a strong positivity in the C6 cells treated with $\mathrm{Cu}(\mathrm{acac})_{2}$, and this indicates that the $\mathrm{Cu}$ compounds initiated cell death by DNA fragmentation, as observed in Figure 6B. At present, we are working to elucidate the underlying mechanisms in this process, by different techniques, like DNA fragmentation, Anexin V/7-ADD, and the participation of diverse caspases, like caspase-3 expression by Western blot, a typical mediator of apoptosis pathway.

\section{Discussion}

The surface of $\mathrm{TiO}_{2}$ was functionalized with GABA, amine, sulphate, and phosphate groups, in a similar manner to the one used when we previously functionalized cryptomelane (a crystalline phase of manganese oxide) materials with the purpose of obtaining highly biocompatible mesoporous oxides..$^{33} \mathrm{~A}$ main achievement of this research was to again functionalize the oxide's surface with phosphate, sulfate, and amine groups in order to obtain a material biocompatible with the cells of rats, understanding that a functionalized oxide surface recognizes functional groups on the cell membrane. The cell membrane is a fluid mosaic of lipids, proteins, and carbohydrates. Its framework consists of a double layer of phospholipids. Two layers of phospholipid molecules self-assemble so that their water

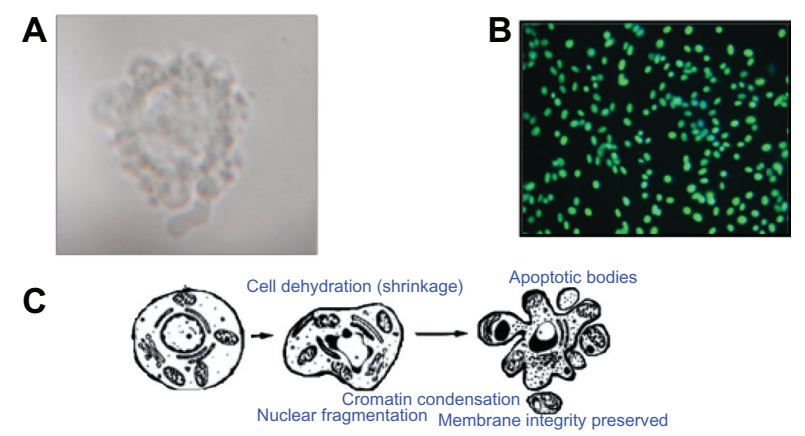

Figure 6 Apoptotic cell death. (A) Image of a dead cell when the cell population was treated with $\mathrm{Cu}(\mathrm{acac})_{2}$. The formation of apoptotic bodies was observed, suggesting an apoptotic cell death mechanism. (B) DNA fragmentation observed by TUNEL assay. (C) Diagrammatic scheme of the apoptotic process carried out in a cell. Abbreviations: $\mathrm{Cu}(\mathrm{acac})_{2}$, copper (II) acetylacetonate; TUNEL, TdT-mediated dUTP nick end labeling (TUNEL) assay. soluble (hydrophilic) heads form the surface and the interior of the membrane, and the water insoluble (hydrophobic) tails face each other. The principal idea was that sulfate and phosphate anchored on the oxide's surface would interact with the extracellular polar head of phospholipids in the cell membrane. All these interactions are stable and produce high biocompatibility of the oxide with the cells.

We functionalized the surface of $\mathrm{TiO}_{2}$ with sulfate, phosphate, and GABA groups using different precursors. However, the infrared results revealed the existence of these groups, which indicates that the functionalization did not depend on the precursor used. ${ }^{22}$ Further, these studies indicated that GABA molecules were linked to the surface of $\mathrm{TiO}_{2}$ through the carboxylic groups, since these groups were not identified by this technique. Therefore, the amine groups remained free to interact with hydrophobic species in the cell membrane. On the other hand, the pyridine adsorption (data not shown) revealed acid sites of the Lewis as Brönsted type, which could generate a positive charge on the surface of $\mathrm{TiO}_{2}$. We propose that the positive charge generated on the surface of $\mathrm{TiO}_{2}$ (by its functionalization) attracted the negative charges on the cell membrane and/or, vice versa, the positive charges inside the cell membrane attracted the negatively charged surface of $\mathrm{TiO}_{2}$, as is proposed in Figure 7, where the cells are surrounding the $\mathrm{TiO}_{2}$. The interactions take place between the amine and carboxylic groups on the cell membrane (which has a negative charge) and the surface of positively charged Ti-OH. However, we cannot discard the existence of negative charges on the surface of $\mathrm{TiO}_{2}$, which may interact with positive and hydrophilic sites of the cell membrane. These interactions or attractions generate recognition between the cells and $\mathrm{TiO}_{2}$, thus producing high biocompatibility of the latter.

The inorganic oxides obtained by the sol-gel procedure produce highly porous solids, by generating nanoparticles that are polymerized over time and form a three-dimensional network with large pores (Figure 8). The nanoparticles are formed by the hydrolysis and condensation of a solution of titanium n-butoxide that initially form - Ti-O-Ti-species rapidly from octahedral polymer $\left(\mathrm{TiO}_{6}\right)$ units, which are condensed into the network structure of $\mathrm{TiO}_{2}$, yielding a porous solid. The pores can host a variety of molecules, including drugs, which can subsequently be released in an adequate medium. In this case, $\mathrm{Cu}(\mathrm{acac})_{2}$ and $\mathrm{Cu}(\mathrm{Oac})_{2}$ were hosted into the $\mathrm{TiO}_{2}$ network and then released in vitro, in an aqueous solution and in cell cultures. The release kinetics of the $\mathrm{Cu}$ complexes released from the porous structure of $\mathrm{TiO}_{2}$ can be affected by the porosity. The textural properties are affected by two factors: the crystalline phase formed and the $\mathrm{Cu}$ complex loaded. 


\section{Functionalized \\ surface of $\mathrm{TiO}_{2}$}

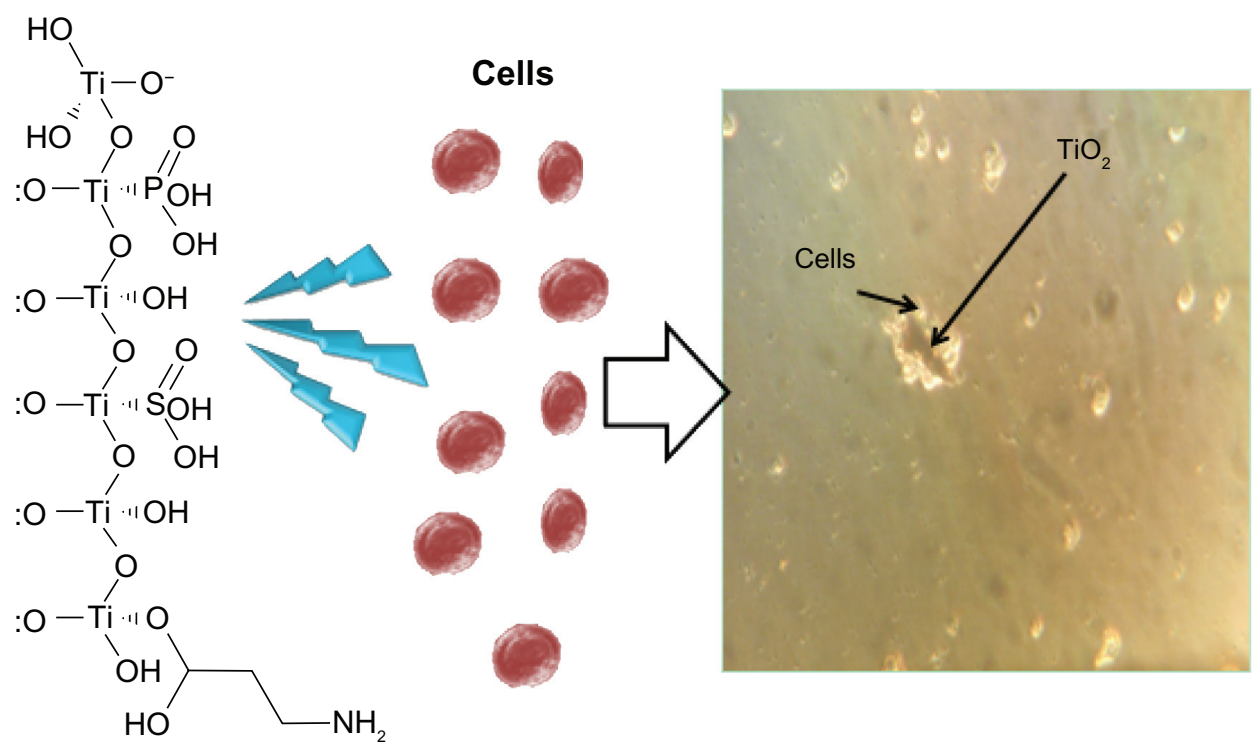

Figure 7 Schematic representation of the functionalization of the surface of titania $\left(\mathrm{TiO}_{2}\right)$, which attracts the cell due to the presence of charges in its cell membrane. Note: The cells are attached around $\mathrm{TiO}_{2}$ by attractions between the surface of $\mathrm{TiO}_{2}$ and the cell membrane.

Samples with a crystalline phase show lower surface areas, while amorphous samples have larger surface areas. This is due to the fact that crystalline solids tend not to have a surface area. In the case of the $\mathrm{Cu}(\mathrm{acac})_{2} / \mathrm{TiO}_{2}$ sample, a crystalline portion was generated by the formation of bonds between the titanium atoms and the acetylacetonate ligands, with the consequent formation of bidented bindings to form crystalline $\mathrm{Ti}(\mathrm{acac})_{2}$. In Figure 2, it is possible observe crystalline islands in the amorphous morphology of $\mathrm{TiO}_{2}$, which caused a reduction of the whole surface area. In a similar way, the presence

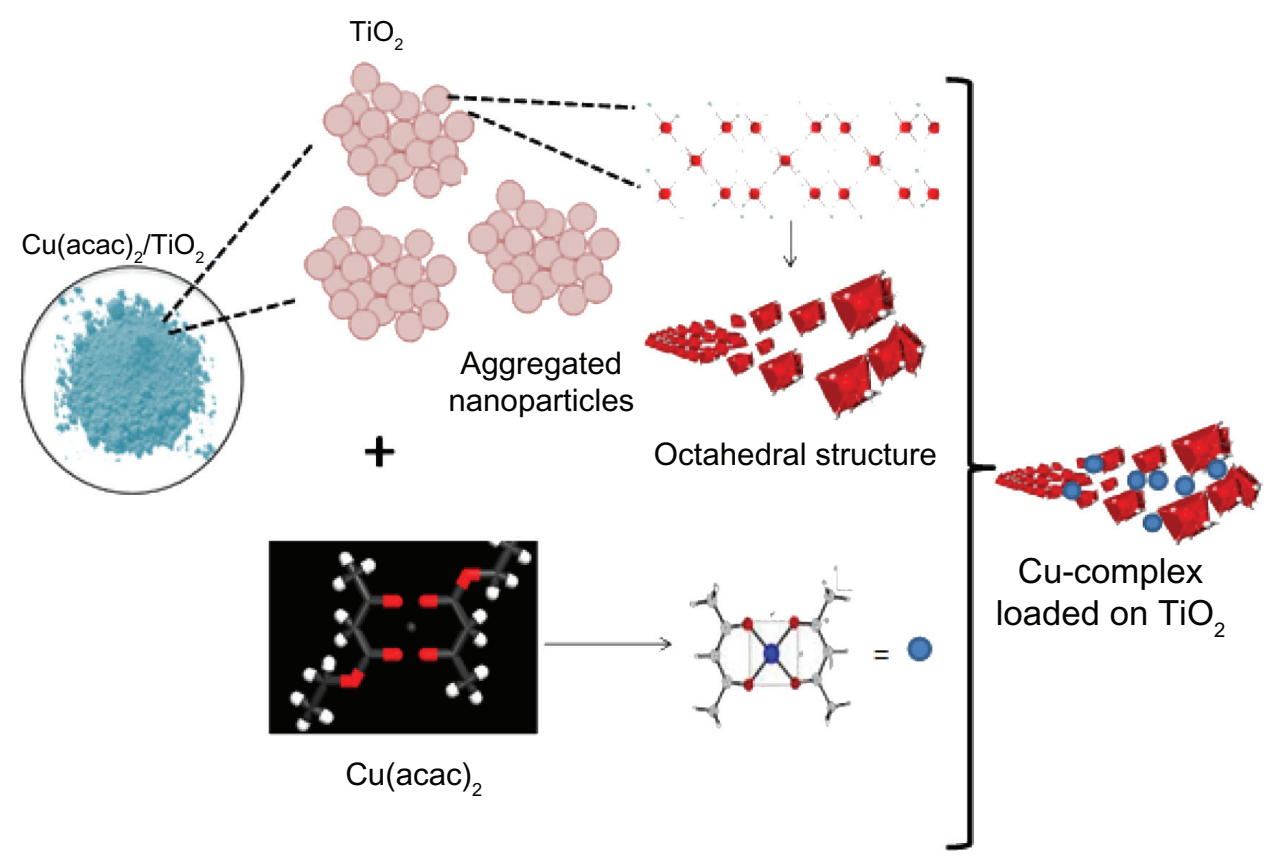

Figure 8 Schematic representation of $\mathrm{Cu}-\mathrm{TiO}_{2}$ materials obtained by the sol-gel method.

Notes: The final product obtained is a fine powder, which consists of aggregated nanoparticles that form the three-dimensional network of TiO ${ }_{2}$ with a porous structure where the copper complexes are hosted.

Abbreviations: $\mathrm{Cu}$, copper; $\mathrm{Cu}(\mathrm{acac})_{2}$, copper (II) acetylacetonate; $\mathrm{TiO}_{2}$, titania. 
of a small quantity of crystalline anatase phase in $\mathrm{TiO}_{2}$ alone reduced its surface area. In contrast, only one amorphous phase was found in the $\mathrm{Cu}(\mathrm{Oac})_{2} / \mathrm{TiO}_{2}$ sample, which showed the highest surface area (due to the fact that amorphous materials yield porous materials with high surface areas). On the other hand, the surface area, pore volume, and pore diameter in $\mathrm{TiO}_{2}$ decreased when $\mathrm{Cu}(\mathrm{acac})_{2}$ molecules were loaded. This fact suggests that a portion of the $\mathrm{Cu}$ molecules were adsorbed on the surface of the $\mathrm{TiO}_{2}$, and another portion occluded the pores without filling them totally. On the other hand, the surface area and pore volume increased when $\mathrm{Cu}(\mathrm{Oac})_{2}$ was loaded on $\mathrm{TiO}_{2}$, while the pore diameter decreased. We can assume that the $\mathrm{Cu}$-complex molecules delayed anatase formation in this sample, producing amorphous materials with high surface areas. Further, this sample produced the highest pore size, which may explain why in the first release step, the $\mathrm{Cu}(\mathrm{Oac})_{2}$ molecules were released faster and in greater amount than the $\mathrm{Cu}(\mathrm{acac})_{2}$ molecules. The $\mathrm{Cu}(\mathrm{Oac})_{2}$ molecules were more exposed to the medium, thus they dissolved much faster, while the $\mathrm{Cu}(\mathrm{acac})_{2}$ molecules had to leave the pores to be able to concentrate in the medium, thus taking more time to complete the process. In the second step, the $n$ values were of 0.16 and 0.06 for $\mathrm{Cu}(\mathrm{acac})_{2}$ and $\mathrm{Cu}(\mathrm{Oac})_{2}$, respectively. These close-tozero values correspond to a zero-order release kinetics, where the drug-release stage was dominated by the diffusion of the drug through the mesoporous surface. This second stage was affected by the pore size and the interactions between the surface of $\mathrm{TiO}_{2}$ and the $\mathrm{Cu}$ complexes. After 20 hours, the $\mathrm{Cu}$ complex release in both samples was ruled by the same slow diffusion process.

In a previous work, ${ }^{22}$ we reported the toxic effect on a $\mathrm{C} 6$ cell line of $\mathrm{Cu}(\mathrm{Oac})_{2}$ alone and loaded at low concentrations on $\mathrm{TiO}_{2}$. We found that the low $\mathrm{Cu}(\mathrm{Oac})_{2}$ concentration of $15.75 \mathrm{mg} / \mathrm{mL}$ was enough to kill more than $50 \%$ of C6 cells. However, a high concentration of $\mathrm{Cu} / \mathrm{TiO}_{2}$ was required to obtain the same effect. A highlight of this previous work was the discovery of $\mathrm{Cu}(\mathrm{Oac})_{2}$ 's high toxicity in cancer cells, which hinted at its great possibilities as a cancer therapeutic. With this in mind we suggest that, in a similar way, other $\mathrm{Cu}$ complexes, such as $\mathrm{Cu}(\mathrm{acac})_{2}$, may also have anticancer properties. In this work, we are reporting the efficient anticancer properties of $\mathrm{Cu}(\mathrm{Oac})_{2}$ and $\mathrm{Cu}(\mathrm{acac})_{2}$. Our first evidence was the presence of apoptotic bodies in the treated cell population, as shown in Figure 6. This phenomenon was characterized by (1) the shrinking of the cell, its deformation, and its loss of contact with neighboring cells; (2) the development of "buds" on the cell surface; (3) the degradation of the cell chromatin and the margination of the chromatin "products" at the nuclear membrane; (4) the breakdown of mitochondria and the release of cytochrome c to the cytosol; and (5) the cellular breakup into small, compact, membrane-contained fragments (apoptotic bodies), ${ }^{34}$ where the integrity of the cell membrane was preserved. DNA fragmentation observed by tunnel assay (Figure 6) supported this finding.

In general terms, we propose that $\mathrm{Cu}$ complexes taken up by cells can induce a global apoptotic mechanism, as shown in Figure 9. Within this global mechanism, various individual mechanisms of apoptosis may occur. Figure 9 shows that functionalized $\mathrm{TiO}_{2}$ was attracted by the cells and, once in contact with the cell membrane, $\mathrm{TiO}_{2}$ released the $\mathrm{Cu}$-complex molecules, which crossed the cell membrane thorough the intracellular spaces. Once inside the cell, the $\mathrm{Cu}$-complex molecules may interfere in diverse biological cell processes, while the mechanism of the widely used cis-Pt consists of only one-way action (cross-linking with the DNA).

It is likely that $\mathrm{Cu}$ complexes interact with enzymes and inhibit vital cell functions instead of interacting with DNA to induce cross-links. However, any of the following apoptotic mechanisms may occur:

1. The $\mathrm{Cu}$-complex molecules may interact with the mitochondria to generate an adenosines diphosphate depletion resulting in low glucose production. Glucose is used as a source of carbon to produce ribose, through the pentose phosphate pathway. Ribose-5-phosphate is then used to make RNA and DNA. Moreover, glycolytic intermediates, such as pyruvate, are used to produce nonessential amino acids, such as alanine. Cells also require amino acids, such as glutamine, to make other amino acids and proteins. Waste is secreted in the form of lactate (mostly from glycolysis) and ammonia (from catabolism to amino acids). ${ }^{35}$

2. The $\mathrm{Cu}$ complexes may interact with the cell nucleus to fragment the DNA. Various $\mathrm{Cu}$ (II) complexes have shown either partial intercalation or groove binding with DNA base pairs. In one study, ${ }^{36}$ the $\mathrm{Cu}$ complexes were cytotoxic to HeLa cell lines as well as to brine shrimp larvae, with low half maximal inhibitory concentration $\left(\mathrm{IC}_{50}\right)$ and half maximal lethal concentration (LC50) values. All complexes cleave supercoiled circular plasmid DNA by a hydrolytic cleavage mechanism in the absence of any externally added reagent. ${ }^{36}$

3. It is widely acknowledged that various $\mathrm{Cu}$ complexes are involved in the process of generating reactive oxygen species, which may induce the apoptosis of various cancer cells, especially drug-resistant ones. ${ }^{37}$ 


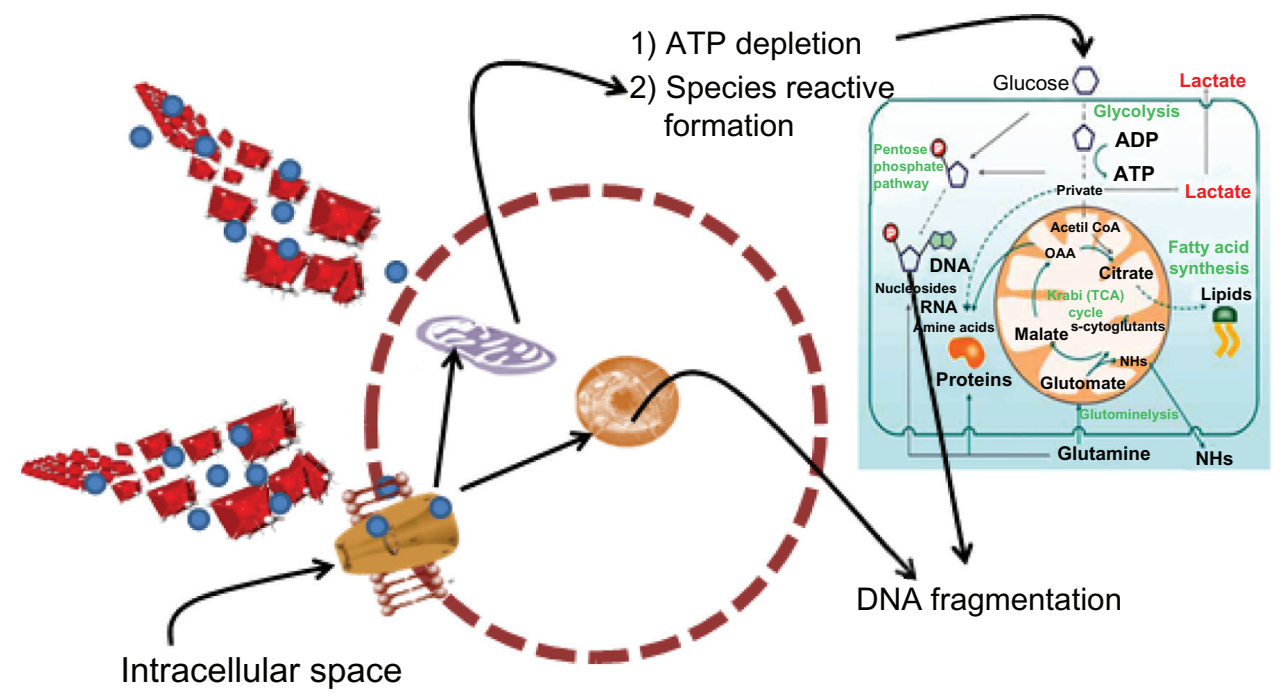

Figure 9 Global schematization of cell death by an apoptotic mechanism due to the action of copper complexes.

Notes: Titania is close to the cell membrane and releases the copper complex, which cross the cell membrane through the cell spaces. Once the copper complex is located within the cell it can reach the mitochondria and produce a decrease in the formation of ATP, thus diminishing the glucose concentration to low levels, which does not allow the formation of nitrogenous bases. In the mitochondria the copper complex may produce reactive species capable of inducing an apoptotic death. The copper complexes may also reach the cell nucleus and create links with the DNA base pairs by intercalation or groove binding.

Abbreviations: DNA, deoxyribonucleic acid; ADP, adenosine diphosphate; RNA, ribonucleic acid; ATP, adenosine triphosphate.

\section{Conclusion}

1. New anticancer properties of $\mathrm{Cu}(\mathrm{Oac})_{2}$ and $\mathrm{Cu}(\mathrm{acac})_{2}$ complexes were found by treating different cancer cell lines with those compounds.

2. Highly biocompatible $\mathrm{TiO}_{2}$ was obtained by functionalizing its surface with sulfate, phosphate, and GABA molecules, which in certain aspects are similar to the hydrophilic heads of phospholipids in the double layer of the cell membrane. A strong attraction between the surface of $\mathrm{TiO}_{2}$ and the cell membrane was produced, without producing any damage to the cell membrane.

3. The results indicate that a single-step synthesis of $\mathrm{Cu} / \mathrm{TiO}_{2}$ allowed, on the one hand, a successful functionalization of $\mathrm{TiO}_{2}$ and, on the other hand, the adequate incorporation of the $\mathrm{Cu}$ complexes into the $\mathrm{TiO}_{2}$ matrix, without any changes in the latter's original structure.

4. It was observed that the addition of the $\mathrm{Cu}$ complexes to the $\mathrm{TiO}_{2}$ network produced an effect on the crystalline phases that were formed as well as on the textural properties. A mix of amorphous and anatase phases were formed on the funtionalized- $\mathrm{TiO}_{2}$, while in the samples containing the complexes, an amorphous phase was formed. In consequence, the highest surface area was obtained from the amorphous samples.

5. The $\mathrm{Cu}$ complex release mechanism can be divided into two steps: the $\mathrm{Cu}(\mathrm{Oac})_{2}$ molecules were released by means of a first-order process governed by a diffusion process, while $\mathrm{Cu}(\mathrm{acac})_{2}$ molecules were released by nontypical diffusion. In both complexes, the release during the second stage was slower, with a diffusion exponent " $n$ " close to zero and a constant drug release rate until the exhaustion of the drug.

6. The cytotoxic effect of $\mathrm{Cu}$ complexes, $\mathrm{Cu}-\mathrm{TiO}_{2}$ and cis-Pt, in a dose-dependent manner, was observed in all the cell lines. $\mathrm{Cu}$ complexes alone and those loaded on $\mathrm{TiO}_{2}$ exerted a better cytotoxic effect towards all cells than did the cis-Pt compound.

7. Low concentrations of $\mathrm{Cu}$ complexes alone were necessary to obtain $90 \%$ cell death, while high concentrations of cis-Pt were necessary to obtain the same effect.

8. A probable apoptotic mechanism of cell death may be occurring; however, in future stages of our research, we are planning to perform studies to determine which cell death mechanism is taking place.

9. According to their efficiency, we found no difference between using either acetate or acetylacetonate ligands on the $\mathrm{Cu}$ complexes.

\section{Acknowledgments}

Thanks to CONACYT-México and ICyTDF for their financial support for this research through projects 102631 and PICDS08-12, respectively. Also, the authors thank students Jesús García Patiño and Miriam López García for their help in improving some of the figures. 


\section{Disclosure}

The authors report no conflicts of interest in this work.

\section{References}

1. Siegel R, Ward E, Brawley O, Jemal A. The impact of eliminating socioeconomic and racial disparities on premature cancer deaths. $\mathrm{Ca}$ Cancer J Clin. 2011;61(4):212-236.

2. Jemal A, Bray F, Center MM, Ferlay J, Ward E, Forman D. Global cancer statistics. Ca Cancer J Clin. 2011;61(2):69-90.

3. Fernandez-Fernandez A, Manchanda R, McGoron AJ. Theranostic applications of nanomaterials in cancer: drug delivery, image-guided therapy, and multifunctional platforms. Appl Biochem Biotechnol. 2011; 165(7-8):1628-1651.

4. Wang X, Wang Y, Chen ZG, Shin DM. Advances of cancer therapy by nanotechnology. Cancer Res Treat. 2009;41(1):1-11.

5. Rosenberg B, VanCamp L, Trosko JE, Mansour VH. Platinum compounds: a new class of potent antitumour agents. Nature. 1969; 222(5191):385-386.

6. Kelland L. The resurgence of platinum-based cancer chemotherapy. Nat Rev Cancer. 2007;7(8):573-584.

7. Bogdanović G, Kojić V, Srdić T, et al. Growth effects of some platinum(II) complexes with sulfur-containing carrier ligands on MCF7 human breast cancer cell line upon simultaneous administration with Taxol. Met Based Drugs. 2002;9(1-2):33-43.

8. Kendall J, Liu Q, Bakleh A, et al. Oncogenic cooperation and coamplification of developmental transcription factor genes in lung cancer. Proc Natl Acad Sci U S A. 2007;104(42):16663-16668.

9. Miller RP, Tadagavadi RK, Ramesh G, Reeves WB. Mechanisms of cisplatin nephrotoxicity. Toxins. 2010;2(11):2490-2518.

10. Faubel S, Lewis EC, Reznikov L, et al. Cisplatin-induced acute renal failure is associated with an increase in the cytokines interleukin (IL)1 beta, IL-18, IL-6, and neutrophil infiltration in the kidney. J Pharmacol Exp Ther. 2007;322(1):8-15.

11. Tardito S, Marchiò L. Copper compounds in anticancer strategies. Curr Med Chem. 2009;16(11):1325-1348.

12. Iakovidis I, Delimaris I, Piperakis SM. Copper and its complexes in medicine: a biochemical approach. Mol Biol Int. Epub June 15, 2011.

13. Hancock CN, Stockwin LH, Han B, et al. A copper chelate of thiosemicarbazone NSC 689534 induces oxidative/ER stress and inhibits tumor growth in vitro and in vivo. Free Radic Biol Med. 2011;50(1): $110-121$.

14. Rajalakshmi S, Weyhermüller T, Freddy AJ, Vasanthi HR, Nair BU. Anomalous behavior of pentacoordinate copper complexes of dimethylphenanthroline and derivatives of terpyridine ligands: studies on DNA binding, cleavage and apoptotic activity. Eur J Med Chem. 2011;46(2):608-617.

15. Santini $C$, Pellei M, Papini $G$, et al. In vitro antitumour activity of water soluble $\mathrm{Cu}(\mathrm{I}), \mathrm{Ag}(\mathrm{I})$ and $\mathrm{Au}(\mathrm{I})$ complexes supported by hydrophilic alkyl phosphine ligands. J Inorg Biochem. 2011;105(2):232-240.

16. Patitungkho S, Adsule S, Dandawate P, Padhye S, Ahmad A, Sarkar FH. Synthesis, characterization and anti-tumor activity of moxifloxacincopper complexes against breast cancer cell lines. Bioorg Med Chem Lett. 2011;21(6):1802-1806.

17. Patra AK, Bhowmick T, Roy S, Ramakumar S, Chakravarty AR. Copper(II) complexes of L-arginine as netropsin mimics showing DNA cleavage activity in red light. Inorg Chem. 2009;48(7):2932-2943.

International Journal of Nanomedicine

\section{Publish your work in this journal}

The International Journal of Nanomedicine is an international, peerreviewed journal focusing on the application of nanotechnology in diagnostics, therapeutics, and drug delivery systems throughout the biomedical field. This journal is indexed on PubMed Central, MedLine, CAS, SciSearch $\AA$, Current Contents ${ }^{\circledR} /$ Clinical Medicine,
18. Tseng TS, Burstyn JN. Synthesis and DNA cleavage activity of a bifunctional intercalator-linked copper (II) macrocycle. Chem Commun (Camb). 2008;(46):6209-6211.

19. Tardito S, Bassanetti I, Bignardi C, et al. Copper binding agents acting as copper ionophores lead to caspase inhibition and paraptotic cell death in human cancer cells. J Am Chem Soc. 2011;133(16):6235-6242.

20. López T, Recillas S, Guevara P, Sotelo J, Alvarez M, Odriozola JA. Acta Biomater. 2008;4(6):2037-2044.

21. López T, Figueras F, Manjarrez J, et al. Catalytic nanomedicine: a new field in antitumor treatment using supported platinum nanoparticles. In vitro DNA degradation and in vivo tests with $\mathrm{C} 6$ animal model on Wistar rats. Eur J Med Chem. 2010;45(5):1982-1990.

22. López T, Ortiz-Islas E, Guevara P, Rios JV. Preparation and characterization of copper compounds co-gelled with nanostructured $\mathrm{TiO}_{2}$ materials to be used in cancer treatment. Sci Adv Mater. 2012;4:579-583.

23. Wang ZL. Characterization of nanophase materials. In: Wang ZL, editor. Transmission Electron Microscopy and Spectroscopy of Nanoparticles. Weinheim: Wiley-VCH Verlag GmbH; 2000:37-41.

24. Leonard K. TEM and Electron Diffraction, College of Engineering and Applied Science, U Cincinnati; 1999. Available from: http://www.eng. uc.edu/ gbeaucag/Classes/XRD/Labs/Keithhtml/Keith.pdf. Accessed. August 12, 2012.

25. López T, Alvarez M, González RD, et al. Synthesis, characterization and in vitro cytotoxicity of $\mathrm{Pt}_{-} \mathrm{TiO}_{2}$ nanoparticles. Adsorption. 2011;17: 573-581.

26. Bokhimi X, Morales A, Novaro O, et al. Effect of copper precursor on the stabilization of titania phases, and the optical properties of $\mathrm{Cu} / \mathrm{TiO}_{2}$ prepared with the sol-gel technique. Chem Mater. 1997;9:2616-2620.

27. Williams DB, Carter CB. Transmission Electron Microscopy. A Textbook for Materials Science. New York: Plenum Press; 1996.

28. Brunauer S, Deming LS, Edwards Deming W, Teller E. On a theory of the van der Waals adsorption of gases. JAm Chem Soc. 1940;62(7):1723-1732.

29. López T, Ortiz E, Alexander-Katz R, Basaldella E, Bokhimi X. Cortisol controlled release by mesoporous silica. Nanomedicine. 2009;5(2): 170-177.

30. López T, Ortiz E, Meza D, et al. Controlled release of phenytoin for epilepsy treatment from titania and silica based materials. Mat Chem Phy. 2011;126:922-929.

31. Peppas NA. Analysis of Fickian and non-Fickian drug release from polymers. Pharm Acta Helv. 1985;60(4):110-111.

32. Mosmann T. Rapid colorimetric assay for cellular growth and survival: application to proliferation and cytotoxicity assays. J Immunol Methods. 1983;65(1-2):55-63.

33. López T, Ortiz E, Alvarez M, et al. Catalytic nanomedicine: Functionalisation of nanostructured cryptomelane. Mat Chem Phy. 2010;120:518-525.

34. Papaliagkas V, Anogianaki A, Anogianakis G, Ilonidis G. The proteins and the mechanisms of apoptosis: A mini-review of the fundamentals. Hippokratia. 2007;11(3):108-113.

35. Muñoz-Pinedo C, El Mjiyad N, Ricci JE. Cancer metabolism: current perspectives and future directions. Cell Death Dis. 2012;3:e248.

36. Barve A, Kumbhar A, Bhat M, et al. Mixed-ligand copper(II) maltolate complexes: synthesis, characterization, DNA binding and cleavage, and cytotoxicity. Inorg Chem. 2009;48(19):9120-9132.

37. Mookerjee A, Basu JM, Majumder S, et al. A novel copper complex induces ROS generation in doxorubicin resistant Ehrlich ascitis carcinoma cells and increases activity of antioxidant enzymes in vital organs in vivo. BMC Cancer. 2006;6:267.

\section{Dovepress}

Journal Citation Reports/Science Edition, EMBase, Scopus and the Elsevier Bibliographic databases. The manuscript management system is completely online and includes a very quick and fair peer-review system, which is all easy to use. Visit http://www.dovepress.com/ testimonials.php to read real quotes from published authors. 